\title{
Differences by Race, Religiosity, and Mental Health in Preferences for Life-Prolonging Treatment Among Medicare Beneficiaries
}

\author{
Justin J. Sanders, MD, MSc ${ }^{7,2}$, Anna I. Berrier, BA ${ }^{7,3}$, Léonce Nshuti, BA, $M S^{1,4}$, \\ James A. Tulsky, $M D^{1,2}$, and Charlotta Lindvall, $M D, P h D^{1,2}$
}

'Department of Psychosocial Oncology and Palliative Care, Dana-Farber Cancer Institute, Boston, MA, USA; ${ }^{2}$ Division of Palliative Medicine, Brigham and Women's Hospital, Boston, MA, USA; ${ }^{3}$ Department of Health Policy and Management, UNC Gillings School of Global Public Health, Chapel Hill, NC, USA; ${ }^{4}$ Department of Biostatistics, Harvard School of Public Health, Boston, MA, USA.

$\mathrm{J}$ Gen Intern Med 34(10): 1981-3

DOI: $10.1007 / \mathrm{s} 11606-019-05052-0$

(c) Society of General Internal Medicine 2019

\section{INTRODUCTION}

Patient preferences ought to guide clinical decision-making, particularly in serious illnesses where disease-directed therapies are not always effective and may cause additional suffering. Yet, clinicians commonly struggle to engage seriously ill patients and their families in conversations about treatment preferences, ${ }^{1}$ and may leave these conversations still unaware of patients' wishes. ${ }^{2}$ When compared to Whites, African Americans may have different end-of-life (EOL) care preferences, which may impact the degree to which they are honored. ${ }^{3}$ We lack understanding about how widespread differences in preferences are. Better population-level data on patient preferences may help prepare clinicians for such discussions about goals of care.

\section{METHODS}

We used the National Health and Aging Trends Study (NHATS) to assess predictors of EOL treatment preference in two hypothetical scenarios. ${ }^{4}$ NHATS, a longitudinal cohort study of a nationally representative sample of Medicare beneficiaries aged 65 and older, oversamples non-Hispanic blacks and those aged 90 and older. Our cross-sectional analysis focused on a supplemental module on end-of-life planning fielded to a random one-third of samples from round 2 participants $(n=2015$; response rate $84 \%)$.

The primary outcomes were dichotomous responses- "receive life prolonging treatments" or "stop all treatments"- to a question about EOL care preferences in two hypothetical scenarios: (1) "What if you could speak, walk, and recognize others, but you were in constant, severe physical pain" ("severe pain"); and (2) "What if you were not in pain, but could not speak, walk, or recognize others?" ("severe disability"). We used descriptive statistics to characterize the sample population using a

Published online May 29, 2019 priori-determined sociodemographic and health-related covariates. We used chi-square test statistics to compare proportions of those who indicated preference to receive or stop life-prolonging treatments in both scenarios. Using a model informed by the literature, we then used multivariable logistic regression to determine predicted prevalence of factors associated with accepting life-prolonging treatment in both scenarios. We analyzed data using STATA 15.1 (StataCorp, College Station, TX).

\section{RESULTS}

Table 1 highlights sociodemographic and health characteristics of those who said they would either receive or stop all life-prolonging treatments in both scenarios (therefore showing a strong preference either for or against aggressive treatment near end of life). We detected significant differences by race and ethnicity, religiosity, education status, income, and self-reported depression. In total, $90.3 \%$ of non-Hispanic Whites said they would stop life-prolonging treatments in the setting of severe pain and disability compared to $64.4 \%$ of Black respondents $(p<0.001)$. In addition, greater religiosity, less education, and lower income all predicted a preference for more aggressive treatment. These differences all persisted in the multivariable logistic regression (Table 2).

\section{DISCUSSION}

In this nationally representative sample of Medicare beneficiaries, a majority of respondents in all groups indicated a preference to stop all treatments in the hypothetical setting of severe pain or disability. However, being Black or Hispanic, considering religion to be of somewhat or high importance, having less than a high school education, and having an annual income of $\$ 25,000$ or less each independently predicted willingness to undergo life-prolonging treatment in both scenarios. Our study demonstrates independent association between low education levels and low annual income with preference to 
Table 1 Characteristics of Those Who Hypothetically Stop or Receive Life-Prolonging Treatments in Both Settings of Constant and Severe Pain and Inability To Walk, Talk, or Recognize Others (Weighted Percentages)

\begin{tabular}{|c|c|c|c|}
\hline Characteristic & $\begin{array}{l}\text { Stop all life- } \\
\text { prolonging } \\
\text { treatments } \\
\% \text { of total } \\
\text { sample }\end{array}$ & $\begin{array}{l}\text { Receive all life- } \\
\text { prolonging } \\
\text { treatments } \\
\% \text { of total } \\
\text { sample }\end{array}$ & $p$ value \\
\hline \multicolumn{3}{|l|}{ Sex } & \multirow[t]{3}{*}{0.09} \\
\hline Male & 45.8 & 53.4 & \\
\hline Female & 54.2 & 46.6 & \\
\hline Age $\geq 85$ & 10.3 & 13.3 & 0.15 \\
\hline \multicolumn{3}{|l|}{ Age categories } & \multirow[t]{4}{*}{0.35} \\
\hline $65-74$ & 57.2 & 57.2 & \\
\hline $75-84$ & 32.5 & 29.5 & \\
\hline$\geq 85$ & 10.3 & 13.3 & \\
\hline \multicolumn{3}{|l|}{ Marital status } & \multirow[t]{7}{*}{0.08} \\
\hline Married & 51.1 & 52.9 & \\
\hline Living with partner & 4.1 & 5.2 & \\
\hline Separated & 0.8 & 2.7 & \\
\hline Divorced & 12.3 & 9.6 & \\
\hline Widowed & 28.7 & 24.4 & \\
\hline Never married & 3.1 & 5.2 & \\
\hline \multicolumn{3}{|l|}{ Race and ethnicity } & \multirow{5}{*}{$<0.001$} \\
\hline White, non-Hispanic & 85.0 & 55.5 & \\
\hline Black, non-Hispanic & 6.0 & 20.2 & \\
\hline Hispanic & 5.9 & 16.7 & \\
\hline Other & 2.1 & 7.4 & \\
\hline \multicolumn{3}{|l|}{ Religiosity } & \multirow[t]{4}{*}{0.003} \\
\hline Very important & 48.1 & 61.3 & \\
\hline Somewhat important & 19.5 & 21.7 & \\
\hline Not so important & 32.4 & 17.0 & \\
\hline \multicolumn{3}{|l|}{ Educational status } & \multirow[t]{3}{*}{0.001} \\
\hline Less than high school & 19.4 & 32.2 & \\
\hline \multirow{2}{*}{\multicolumn{3}{|c|}{ Annual income }} & \\
\hline & & & \multirow[t]{3}{*}{0.001} \\
\hline$\leq \$ 25,000$ & 38.6 & 58.5 & \\
\hline$>\$ 25,000$ & 61.4 & 41.5 & \\
\hline \multicolumn{3}{|l|}{ Self-reported health } & \multirow[t]{3}{*}{0.08} \\
\hline Fair or poor & 22.1 & 29.0 & \\
\hline \multicolumn{3}{|l|}{ excellent } & \\
\hline Cancer diagnosis & 5.9 & 7.0 & 0.59 \\
\hline Dementia diagnosis & 0.6 & 1.2 & 0.15 \\
\hline History of stroke & 2.8 & 1.5 & 0.25 \\
\hline Painful condition & 26.3 & 28.1 & 0.68 \\
\hline Shortness of breath & 54.2 & 45.1 & 0.42 \\
\hline \multicolumn{3}{|l|}{ ADLS } & \multirow{4}{*}{0.17} \\
\hline 0 & 90.1 & 88.9 & \\
\hline $1-2$ & 8.4 & 7.8 & \\
\hline$\geq 3$ & 1.5 & 3.4 & \\
\hline \multicolumn{3}{|l|}{ Nervous or anxious } & 0.45 \\
\hline Not at all & 65.7 & 65.1 & \\
\hline Several days per week & 26.9 & 23.9 & \\
\hline $\begin{array}{l}\text { More than half the } \\
\text { days }\end{array}$ & 3.9 & 5.4 & \\
\hline Nearly every day & 3.6 & 5.6 & \\
\hline Down, depressed, or hop & less & & 0.02 \\
\hline Not at all & 72.7 & 71.5 & \\
\hline Several days per week & 21.2 & 15.7 & \\
\hline More than half the & 3.6 & 8.4 & \\
\hline $\begin{array}{l}\text { days } \\
\text { Nearly every day }\end{array}$ & & & \\
\hline Nearly every day & 2.6 & 4.5 & \\
\hline
\end{tabular}

Variables that obtained statistical significance are italicized

accept life-sustaining treatment. These findings support other evidence that most individuals prefer comfort-focused care in the setting of severe pain or severe disability, and that sociodemographic differences reflective of underserved communities make one more likely to express preference for lifesustaining treatment. ${ }^{5,6}$ They suggest that people view suffering differently.
Table 2. Association Between Sociodemographic Variables, Health Variables, and Predicted Prevalence of Preference To Receive All Life-Prolonging Treatments in the Settings of Both Severe Pain and Disability

\begin{tabular}{|c|c|c|}
\hline & $\begin{array}{l}\text { Predicted prevalence } \\
\left(\%\left[\begin{array}{ll}95 \% & \mathrm{CI}\end{array}\right)^{1}\right.\end{array}$ & $p$ values $^{2}$ \\
\hline \multicolumn{3}{|l|}{ Gender } \\
\hline Female & $12.3(8.6-16.0)$ & - \\
\hline Male & $17.3(13.5-21.1)$ & 0.07 \\
\hline \multicolumn{3}{|l|}{ Age } \\
\hline$<85$ & $14.9(12.0-17.9)$ & - \\
\hline$\geq 85$ & $12.5(7.3-17.7)$ & 0.96 \\
\hline \multicolumn{3}{|l|}{ Race/ethnicity } \\
\hline White & $9.9(7.4-12.4)$ & - \\
\hline Black/African American & $32.7(26.6-38.8)$ & $<0.001$ \\
\hline Hispanic/Latino & $30.6(15.6-45.6)$ & 0.001 \\
\hline Other & $34.3(9.1-59.5)$ & $<0.001$ \\
\hline \multicolumn{3}{|l|}{ Education } \\
\hline Greater than HS & $14.1(11.4-16.8)$ & - \\
\hline HS diploma or less & $16.2(10.6-21.8)$ & 0.56 \\
\hline \multicolumn{3}{|l|}{ Annual income } \\
\hline$\$ 25,000$ or more & $11.6(8.4-14.8)$ & - \\
\hline Less than $\$ 25,000$ & $18.3(14.1-22.5)$ & 0.01 \\
\hline \multicolumn{3}{|l|}{ Religion } \\
\hline Not so important & $8.1(4.2-12.0)$ & - \\
\hline Somewhat important & $19.5(11.3-27.7)$ & 0.01 \\
\hline Very important & $16.9(13.0-20.9)$ & 0.02 \\
\hline \multicolumn{3}{|l|}{ Depressed } \\
\hline Not at all & $15.4(11.9-18.9)$ & - \\
\hline Several days & $11.2(5.9-16.6)$ & 0.05 \\
\hline More than half the days & $20.5(5.6-35.4)$ & 0.27 \\
\hline Nearly every day & $14.8(1.2-28.3)$ & 0.98 \\
\hline
\end{tabular}

Sample represents a population size: 4,208,898, with 898 observations, 56 strata, and 112 PSUs. Variables that obtained statistical significance are italicized

${ }^{I}$ Predicted prevalence values are the predicted probabilities calculated using the post-estimation margins command following multivariable logistic regression analysis

${ }^{2}$ Compares results for the specific subgroup to the reference group on the basis of the multivariable logistic regression model. The reference group is the first specified subgroup for each independent variable

The hypothetical questions from the NHATS survey tell us something about group differences but nothing about personal preference, especially in real circumstances. In the absence of better explanations for why individual preferences differ independently by race, income, or education, clinicians leading advance care planning discussions should cultivate awareness that social determinants may substantially impact the EOL decision-making process. Advance care planning and goals of care discussions should reflect the unique circumstances of the patient with a focus on the personal context surrounding their illness and their experience of suffering. Clinicians can effectively utilize this data not to make assumptions about a given patient, but to prepare themselves to discuss the meaning of different health states with patients by developing effective communication skills.

Acknowledgments: The authors thank Dr. Simo Goshev of IQSS Harvard University for statistical support.

Corresponding Author: Justin J. Sanders, MD, MSc; Department of Psychosocial Oncology and Palliative Care Dana-Farber Cancer Institute, Boston, MA, USA (e-mail: Justin_sanders@dfci.harvard.edu). 
Funding Information The authors received funding for this project through the Sojourns Scholars Program to Dr. Sanders from the Cambia Health Foundation, as well as the American Academy of Hospice and Palliative Medicine Research Scholars Program.

\section{Compliance with Ethical Standards:}

Conflict of Interest: The authors declare that they do not have a conflict of interest.

\section{REFERENCES}

1. Kale MS, Ornstein KA, Smith CB, Kelley AS. End-of-life discussions with older adults. J Am Geriatr Soc. 2016;64(10):1962-1967. https://doi. org/10.1111/jgs. 14285.

2. Bernacki RE, Block SD, American College of Physicians High Value Care Task F. Communication about serious illness care goals: a review and synthesis of best practices. JAMA Intern Med. 2014;174(12):1994-2003. https://doi.org/10.1001/jamainternmed.2014.5271.

3. Mack JW, Paulk ME, Viswanath K, Prigerson HG. Racial disparities in the outcomes of communication on medical care received near death. Arch Intern Med. 2010;170(17):1533-1540. https://doi.org/10.1001/ archinternmed.2010.322.

4. NIoA (NIA). National Health \& Aging Trends Study (NHATS).

5. Cain CL, Surbone A, Elk R, Kagawa-Singer M. Culture and palliative care: preferences, communication, meaning, and mutual decision making. J Pain Symptom Manag. 2018;55(5):1408-1419. https://doi.org/10. 1016/j.jpainsymman.2018.01.007.

6. Balboni TA, Vanderwerker LC, Block SD, et al. Religiousness and spiritual support among advanced cancer patients and associations with end-of-life treatment preferences and quality of life. J Clin Oncol. 2007;25(5):555-560. https://doi.org/10.1200/jco.2006.07.9046.

Publisher's Note Springer Nature remains neutral with regard to jurisdictional claims in published maps and institutional affiliations. 